\title{
DYSFUNCTIONALITY OF TWO-PART TRANSFER PRICING IN INVESTMENT CENTERS' PERFORMANCE ASSESSMENT
}

\author{
Liudmila A. Guzikova* \\ Igor A. Nechitaylo ${ }^{* *}$
}

Received: 17. 5. 2020

Professional paper

Accepted: 15. 9. 2020

UDC 330.322:330.13

DOI https://doi.org/10.30924/mjcmi.25.2.16

\begin{abstract}
The paper discusses the question of the ability of the two-part transfer pricing system to stimulate investment centers to reject projects with positive NPV and to accept projects with negative NPV when there is no external market for intermediate products. The study revealed under which circumstances investment centers can take such dysfunctional decisions and it investigated if these systems can be modified to eliminate negative effects of such circumstances. In order to solve these problems, methods of financial analysis, real options theory and theory of constraints were used and several hypothetical business situations were modelled to exemplify
\end{abstract}

Abstract

\section{INTRODUCTION}

In cases of high decentralization where the structure of the company includes profit centers and investment centers, the duties of transfer pricing must be given to their managers. It is usually accepted that delegating broad authorities to units and creation of such centers can increase the quality and speed of decision making, as well as enhance staff motivation (Horngren et al., 1997). At the same time, in the absence of possible dysfunctional behavior of investment centers when strategic decisions are taken in a decentralized manner. The paper considers the reasons for taking such decisions, such as using average rates of resource costs in calculating the transfer payment, presence of the real options in related projects complex and breaking the five focusing steps of the theory of constraints.

Keywords: transfer price; two-part transfer pricing system; decentralization; investment center; economic profit; real option; theory of constraints

a competitive external market, the establishment of transfer pricing on a cost basis by representatives of profit centers and investment centers can lead to decisions that are not optimal for the company as a whole.

Setting the cost-based transfer price for a unit of an intermediate product usually does not allow adequate inclusion into the price of the long-term marginal production costs or the opportunity costs that arise when there are several options for using

\footnotetext{
Liudmila A. Guzikova (Corresponding author), Peter the Great St. Petersburg Polytechnic University, Politekhnicheskaya, 29, Saint-Petersburg, 195251, Russia, E-mail: guzikova@mail.ru, ORCID: https://orcid.org/00000002-3966-968X

** Igor A. Nechitaylo, Peter the Great St. Petersburg Polytechnic University, Politekhnicheskaya, 29, Saint-Petersburg, 195251, Russia, E-mail: nechitajlo_ia@spbstu.ru, ORCID: https://orcid.org/0000-0002-0925-1565
} 


\section{Journal of Contemporary Management Issues}

limited resources from a unit producing intermediate products. Therefore, decisionmaking by profit centers and investment centers based on such prices can lead to losses and lost profits. These losses and lost profits are an intrafirm analogue of transaction costs introduced in the economics by Coase (1937) and subsequently investigated by Williamson (1985).

The works of Hirshleifer (1956) and Bierman (1959) may be considered first significant studies of this problem. A large contribution to the investigation of costbased transfer pricing methods was made by Samuels (1969). The results of his research were further developed by Tomkins (1990) who combined full costs based pricing with negotiations between responsibility centers in the pragmatic-analytical approach. Transfer pricing based on activity-based costing was proposed by Kaplan and Atkinson (1998). This problem was also investigated by Vaysman (1996), Gox (2000), McAulaya et al. (2001), Sahay (2003), Buus and Brada (2008), Luther and Zverovich (2010), Pfeiffer et al. (2011). However, most of the solutions proposed by these authors are either too complicated for implementation or are associated with general shortcomings in absorption costing, explicated in particular by the founders of the theory of constraints (Goldratt, 1990).

In this regard, transfer pricing system consisting of two parts forming in total the equivalent to the long-term marginal cost of the transferring unit, deserves special attention. The use of two-part prices in the economy is quite common and has been analyzed by a number of authors (e.g. Hayes, 1987; Schlereth et al., 2010). The use of two-part prices in transfer pricing to solve the problem of double monopoly margin was investigated by Lantz (2009) and the use of this system in the service sector by Young (1998).

At the same time, the features of this transfer pricing system application in the investment centers' activities have not been fully studied. It is known that the fundamental criterion for evaluation of investment decisions is the net present value (NPV) for a set of related projects. It can be assumed that in some situations, this transfer pricing system may prompt investment center managers to reject projects with a positive NPV or to accept projects with a negative NPV.

That is why to minimize such alternative costs resulting from application of this transfer pricing system, two tasks must be solved. Firstly, circumstances should be determined when using this transfer pricing system can lead to a fall in business' value. Secondly, the possibility of modifying this system to eliminate the negative effects of these circumstances should be determined.

\section{METHODOLOGY AND MATERIALS}

In order to solve the presented problems, let us simulate three hypothetical business situations of a company which consists of three major production divisions (Figure 1). Division $\mathrm{X}$ is a profit center and produces intermediate products, which are used by divisions and investment centers $\mathrm{Y}$ and $\mathrm{Z}$ to produce end products $\mathrm{A}$ and $\mathrm{B}$, respectively. There are no external markets for the intermediate products while the markets for both end products are close to the market of perfect competition, which allows us to consider the company as a price taker. The products A and B are neither substitutes, nor complementary. 


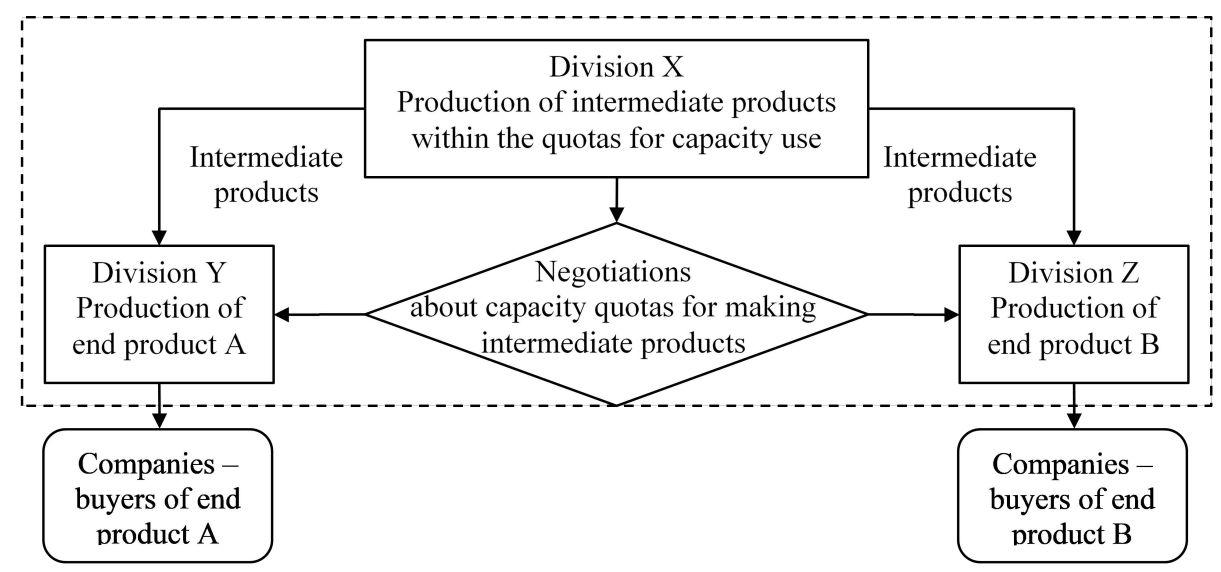

Figure 1. Activity of the company with two-part transfer pricing system and no external markets for intermediate products

In order to evaluate the costs of transactions between centers $\mathrm{X}$ and $\mathrm{Y}$, as well as centers $\mathrm{X}$ and $\mathrm{Z}$, let us accept the simplest version of a two-part transfer pricing system, since building models based on more complex distribution systems of indirect costs, in particular $\mathrm{ABC}$, would significantly complicate them, without changing the nature of the problem. In our case, the model for evaluating these transactions is of the form:

$P_{i}=V_{i}+C_{i}=q_{j i} \cdot v c_{j X}+c p_{i X} \cdot s_{X}$

$s_{X}=\frac{F C_{X}+D P_{X}+A_{X} \cdot k}{c p_{X}}$

$q_{j i} \cdot r_{j X} \leq c p_{i X}$

where $P_{i}$ is the expenditure on transfer operations of the i-th division, including $V_{i}$ - expenses on reimbursement of the variable costs of division $\mathrm{X}$ related to the intermediate products manufacturing, $C_{i}$ is the value of the right to use its production capacity;

$\mathrm{q}_{\mathrm{ji}}$ is the output of the $\mathrm{j}$-th end product by the i-th division (we shall accept it as equal to sales); $\mathrm{vc}_{\mathrm{jx}}$ is the standard variable costs of division $\mathrm{X}$ per output of a unit of the $\mathrm{j}$-th end product;

$r_{j x}$ is the time rate spent on the output of intermediate products by division $\mathrm{X}$ required for the manufacturing of a unit of the $\mathrm{j}$-th end product;

$\mathrm{cp}_{\mathrm{ix}}$ is the part of the production capacity of division $\mathrm{X}$ reserved for the i-th customerdivision (in machine-hours);

$\mathrm{s}_{\mathrm{x}}$ is the rate of one machine-hour of division $\mathrm{X}$;

$\mathrm{cp}_{\mathrm{x}}$ is the production capacity of division X (in machine-hours);

$\mathrm{FC}_{\mathrm{x}}$ is the total estimated fixed costs of division $\mathrm{X}$ assuming that the equipment of this division operates at full capacity (except for the depreciation of the fixed assets of division $\mathrm{X}$ );

$\mathrm{DP}_{\mathrm{x}}$ is the depreciation of the fixed assets of division $\mathrm{X}$;

$A_{x}$ is the assets of division $X$, for which normal profit, i.e. the profit required to 


\section{Journal of Contemporary Management Issues}

reimburse the costs of capital, is calculated by the rate $k$ corresponding to the cost of capital.

In accordance with the conditions of decentralization, the manager of division $\mathrm{X}$ can distribute the production capacities between the consumer divisions through negotiations. It should be noted that it does not exclude the possibility of redistributing the rights to the production capacities of division $\mathrm{X}$ between divisions $\mathrm{Y}$ and $\mathrm{Z}$ using an in-house analogue of the secondary market of these rights. If the participants have full access to the information in such a market, these rights could be acquired by the division that is able to use them in the most effective way and, as a result, could offer the highest price.
In order to simplify the calculations, let us presume that for any option, all factors of future operation cash flows, in particular the demand for products, prices and cost rates, remain unchanged on the planning horizon. That is why, future cash flows from operating activities can be modeled as annuities. The data on available production capacities, standard fixed costs and normal profits of the divisions for the planning month are given in Table 1. On that premise, the rate of one machine hour, which is used to charge for the capacity maintained at the current level, according to (2) is approximately 2.8 thousand rubles. The rates of direct variable costs and equipment operating time costs for the manufacturing of end products are given in Table 2.

Table 1. Data on production capacities, fixed costs and normal profits of the company's divisions for the planning month

\begin{tabular}{|c|c|c|c|}
\hline Division $(i)$ & $\begin{array}{l}\text { Production capacity, } \\
\text { machine-hours }\left(\mathrm{cp}_{\mathrm{i}}\right)\end{array}$ & $\begin{array}{l}\text { Fixed costs, apart from depreciation } \\
\text { and expenses for transfer operations, } \\
\text { thousand rubles }\left(\mathrm{FC}_{\mathrm{i}}\right)\end{array}$ & $\begin{array}{l}\text { Depreciation and normal profit, } \\
\text { thousand rubles }\left(\mathrm{DP}_{\mathrm{i}}+\mathrm{A}_{\mathrm{i}} \cdot \mathrm{k}\right)\end{array}$ \\
\hline $\mathrm{X}$ & 2100 & 3041 & 2839 \\
\hline $\mathrm{Y}$ & 1380 & 1176 & 723 \\
\hline $\mathrm{Z}$ & 1350 & 1065 & 571 \\
\hline
\end{tabular}

Table 2. Rates of direct variable costs and machine time for output of end products of the company on the planning horizon

\begin{tabular}{|l|l|l|l|l|l|l|}
\hline \multirow{2}{*}{ Product $(\mathrm{j})$} & \multicolumn{5}{|l|}{$\begin{array}{l}\text { The rate of variable costs for the manufacturing of } \\
\mathrm{a} \text { unit of the end product in divisions, rubles }\left(\mathrm{vc}_{\mathrm{ji}}\right)\end{array}$} & $\begin{array}{l}\text { The running time of equipment required } \\
\text { for the manufacturing of the end product } \\
\text { in the divisions, machine-hours / thousand } \\
\text { units }\left(\mathrm{r}_{\mathrm{ji}}\right)\end{array}$ \\
\cline { 2 - 8 } & $\mathrm{X}$ & $\mathrm{Y}$ & $\mathrm{Z}$ & $\mathrm{X}$ & $\mathrm{Y}$ & $\mathrm{Z}$ \\
\hline $\mathrm{A}$ & 25.00 & 15.00 & & 6.40 & 11.00 & \\
\hline $\mathrm{B}$ & 40.00 & & 20.00 & 9.00 & & 8.50 \\
\hline
\end{tabular}

The enterprise has one project for expanding production capacities in each division, with details presented in Table 3. If necessary, these projects can be carried out independently of each other. In order to simplify the calculations, let us suppose that the time needed for the purchase and installation of additional equipment for each of these projects is negligible and the projects will begin to produce an effect within the first month after they get adopted. Moreover, the period of use of the main 
technological equipment for each of these projects until the next major investment is the same and equals to 10 years, which we will consider as the planning horizon $(t)$.

Table 3. Data on the starting investments and change in the fixed costs for the projects aimed at expanding the production capacity of divisions

\begin{tabular}{|l|l|c|c|c|}
\hline \multirow{2}{*}{ No. } & \multirow{2}{*}{ Indicator } & \multicolumn{3}{|l|}{$\begin{array}{l}\text { The project aimed at expanding the produc- } \\
\text { tion capacity of the division: }\end{array}$} \\
\cline { 3 - 5 } & & $\mathrm{X}$ & $\mathrm{Y}$ & $\mathrm{Z}$ \\
\hline 1 & $\begin{array}{l}\text { Increase in the production capacity of the division, } \\
\text { machine-hours per month }(\Delta \mathrm{cp})\end{array}$ & 700 & 690 & 680 \\
\hline 2 & Starting investments, thousand rubles $\left(\Delta_{\mathrm{i}}\right)$ & 29800 & 13200 & 5300 \\
\hline 3 & $\begin{array}{l}\text { Increase in the fixed costs of the division after the } \\
\text { project gets adopted (excluding depreciation of fixed } \\
\text { assets), thousand rubles per month }\left(\Delta_{\mathrm{FC}}\right)\end{array}$ & 1040 & 580 & 540 \\
\hline
\end{tabular}

The main differences between the situations to be analyzed below are (i) the conditions at the end product market, (ii) the capacity quotas of division $\mathrm{X}$ that divisions $\mathrm{Y}$ and $\mathrm{Z}$ have in accordance with the agreements reached earlier between them, and (iii) approaches used to evaluate the rate of a machine-hour (Table 4).

The difference between situation 2 and other situations is the option to create the production of new product $\mathrm{D}$, which has been developed by the head office and can be launched on the market in 1 year in case it is in demand. Through organizational means production of the new product can be allocated to a new division with the status of a profit center. Some components necessary for the output of this new product can be made only using the equipment of division $\mathrm{X}$. The standard operating time of this division is 1.9 machine-hours for one thousand of such components. For ultimate simplification, we shall assume that the demand and the price of the new product, as well as the costs for its manufacturing, will be stable for nine years after its possible launch on the market 1 year later. At the moment, demand and price cannot be determined accurately enough. However, starting from the second year and according to preliminary estimates, customers will be ready to buy 65 thousand units of this product every month from the company at a price of 109 rubles per unit. The expected direct variable costs required in division $\mathrm{X}$ to manufacture intermediate products necessary for manufacturing one unit of product $\mathrm{D}$ are 14 rubles, while other variable costs necessary for manufacturing a unit of this product are 32 rubles. The fixed operation costs of the new division (except for the depreciation of fixed assets) is 2,185,000 rubles per month, and the starting investments in the assets of this division is $81,080,000$ rubles. The capital cost rate and the mean square deviation of the rate of return for this project are assumed at the same level as for the company as a whole. 


\section{Journal of Contemporary Management Issues}

Table 4. Differences in business situations

\begin{tabular}{|l|l|c|c|c|}
\hline \multicolumn{2}{|l|}{ Distinctive feature } & Situation 1 & Situation 2 & Situation 3 \\
\hline $\begin{array}{l}\text { Demand for the products of the company, thousand } \\
\text { units per month }\left(\mathrm{q}_{\mathrm{Dj}}\right)\end{array}$ & $\mathrm{A}$ & 125 & 125 & 170 \\
\cline { 2 - 5 } & $\mathrm{B}$ & 210 & 202 & 150 \\
\hline \multirow{2}{*}{ Prices of products, rubles per unit $\left(\mathrm{P}_{\mathrm{j}}\right)$} & $\mathrm{A}$ & 80 & 80 & 90,5 \\
\cline { 2 - 5 } & $\mathrm{B}$ & 96 & 96 & 96 \\
\hline \multirow{2}{*}{$\begin{array}{l}\text { Part of the capacity of division X reserved by other } \\
\text { divisions, machine-hours per month }\left(\mathrm{CP}_{\mathrm{iX}}\right)\end{array}$} & $\mathrm{Y}$ & 800 & 800 & 750 \\
\cline { 2 - 5 } & $\mathrm{Z}$ & 1300 & 1300 & 1350 \\
\hline $\begin{array}{l}\text { Maximum output of products based on the capacity } \\
\text { quota of division X, thousand units per month }\left(\mathrm{q}_{\mathrm{p}}\right)\end{array}$ & $\mathrm{A}$ & 125 & 125 & 117.2 \\
\hline & $\mathrm{B}$ & 144 & 144 & 150 \\
\hline $\begin{array}{l}\text { Method of estimating one machine-hour of operation of } \\
\text { new equipment in division X }\end{array}$ & By average cost & $\begin{array}{l}\text { By marginal } \\
\text { cost }\end{array}$ & $\begin{array}{l}\text { By marginal } \\
\text { cost }\end{array}$ \\
\hline \multirow{2}{*}{\begin{tabular}{l} 
Presence of real options \\
\hline
\end{tabular}} & None & $\begin{array}{l}\text { Option for } \\
\text { creating new } \\
\text { production }\end{array}$ & None \\
\hline
\end{tabular}

In order to learn about dysfunctional behavior of the managers of some investment centers, let us try to anticipate their possible decisions in these conditions. Let us assume that the performance of these centers is regularly assessed based on the economic profit, whose best-known indicator is economic value added (EVA). Therefore, when the managers of the investment centers make decisions, they are guided by the forecasted value of this indicator. So in order to solve the tasks posed, it is necessary to calculate the shift in economic profit due to the project carried out by the investment center, for each situation. Next, NPV has to be calculated for the project or set of projects for each situation. After that, firstly, we should analyze if the conclusions obtained on the basis of the projected economic profit are consistent with the NPV-based conclusions. Secondly, it should be assessed whether the NPV itself was overestimated or underestimated in relation to the value that would have been obtained for the project or a set of projects if investment decisions had been taken in the company in a centralized way.

It is known that conclusions based on economic profit in some cases may contradict conclusions based on the rule of NPV. This problem is solved by obtaining the series of economic profit values within the planning horizon having the sign not opposite to that of NPV with the present value in total equal to NPV. (Tomkins, 1975). The particular solution is provided by the annuity method of depreciation, which allows obtaining the following monthly economic profit series of the i-th investment center on the planning horizon:

$$
\begin{aligned}
& \Delta E V A_{i}=\Delta M P_{i}-\Delta F C_{i}-\Delta A_{i} \cdot \frac{\kappa}{1-(1+k)^{-t}}-\Delta C_{i} \\
& \Delta M P_{i}=\Delta q_{j i} \cdot\left(p_{j}-v c_{j i}-v c_{j X}\right)
\end{aligned}
$$

Future cash flows from the investment project or a set of projects, initiated by the i-th investment center, can be estimated as follows: 
$C F_{i}=\Delta M P_{i}-\Delta F C_{i}-\Delta F C_{i X}$

Based on this, the results of the project evaluated by the i-th investment center in terms of economic profit indicator may be inconsistent with the NPV criterion in case the following equality is broken:

$N P V=C F_{i} \cdot \frac{1-(1+k)^{-t}}{k}-\Delta A_{i}-\Delta A_{i X}+G=\Delta E V A_{i} \cdot \frac{1-(1+k)^{-t}}{k}$ (7)

$\mathrm{G}$ is the value of the real option associated with a set of projects.

It can be seen from formulas (4) and (6) that we abstracted from the factors of taxation and cross-border movement of profits in our calculations. This is done to evaluate purely the managerial consequences of the overall result of the company's work redistributed between the divisions through transfer pricing. Otherwise, these factors could distort the results of the study and require centralized intervention in the operations of the head office.

In addition, when calculating the NPV of these projects, we proceed from the assumption that future cash flows are random variables with a symmetric distribution. Therefore, their median value can be taken as the basis of the discounted cash flow. It will have to be determined by the above algorithm. Discounting is carried out at an annual rate of $20.9 \%$ with a monthly accrual (i.e. $1.74 \%$ per month), while the annual risk-free interest rate is $3 \%$ (i.e. $0.25 \%$ per month). The mean square deviation of the monthly yield on similar assets on the financial market is assumed to be 0.1443 . The terminal value of the projects is set to be zero.

\section{RESULTS}

Let us consider the main options for the development of each of the three situations and their results.

In situation 1, the manager of division $\mathrm{Z}$ expects an increase in demand for product $\mathrm{B}$ and is considering the possibility of expanding the production capacity necessary for the output of the product in the quantities that customers need. According to the terms of the arrangements existing between the managers of the divisions, by the time the decision is taken, division $\mathrm{Z}$ have reserved 1300 machine-hours of operation of the equipment of division $\mathrm{X}$, and division $\mathrm{Y}$ have reserved 800 machine-hours. Taking into account the data in Tables 1 and 2, with the given capacity quotas of division $\mathrm{X}$, divisions $\mathrm{Y}$ and $\mathrm{Z}$ can produce 125 thousand and 144.44 thousand units of product A and product B respectively, which is the best production program considering the production capacities the company has.

To increase the monthly output of product $\mathrm{B}$ by 65.56 thousand units, division $\mathrm{Z}$, first of all, needs to increase its quota in the production capacity of division $\mathrm{X}$. Since unit $\mathrm{Y}$ has no incentives to transfer part of its quota, in order to increase the output of product $\mathrm{B}$, the manager of division $\mathrm{Z}$ will have to initiate a purchase of an additional piece of equipment in division $\mathrm{X}$ by the head office for 29,800 thousand rubles. It will increase its capacity from 2,100 to 2,800 machine-hours per month. In addition, he will have to buy an additional piece of equipment at 5,300 thousand rubles for his own division $\mathrm{Z}$, increasing its production capacity from 1,350 to 2,030 machinehours per month.

Since investments in the equipment of divisions $\mathrm{X}$ and $\mathrm{Z}$ can bring return to 


\section{Journal of Contemporary Management Issues}

division $\mathrm{Z}$ only if the implementation is joint they form a single set of investments. This set of projects has a positive NPV and makes the economic profit of the company grow, as can be seen from column 3 of Table 5. Nevertheless, an increase in the economic profit of the company after the project is adopted in situation No. 1 will not make this indicator grow for division $\mathrm{Z}$.

The fact is that the transfer charge for using the capacity of division $\mathrm{X}$ is based on distribution of indirect costs of this division. In this situation it is calculated from the average rate of a machine-hour, which will decrease from 2.8 thousand rubles to 2.683 thousand rubles per machine-hour. In this case, the marginal rate of a machinehour for the newly commissioned equipment in this division will be approximately 2.333 thousand rubles. Thus, in the case divisions $\mathrm{Y}$ and $\mathrm{Z}$ are charged for the capacity at the new average rate of a machine-hour, the part of saving due the cost reduction calculated per one machine hour in the amount of 93.3 thousand rubles will be redistributed from division $\mathrm{Z}$ in favor of division $Y$, which will make equality (7) break. The result of this redistribution formally has the following form:

$\Delta C_{Y}=p_{X} \cdot\left(s_{X 1}-s_{X 0}\right)=800 \cdot(2,683-2,8) \approx-93.3$

As a result, in case production is expanded, the economic profit indicator for division $\mathrm{Y}$ will increase by 93.3 thousand rubles per month while the value of this indicator for division $\mathrm{Z}$ will go down by 12.2 thousand rubles per month. Therefore, under such conditions the manager of division $\mathrm{Z}$ is likely to reject this complex of investment projects, despite his positive NPV.

In order to eliminate the distorting effect caused by estimating the cost of additional machine time at average rates and to ensure that equality (7) is fulfilled in the following situations, we carry out the estimation at marginal rates:

$$
\Delta C_{i}=\Delta \mathrm{FC}_{\chi \chi}-\Delta A_{\text {XX }} \cdot \frac{k}{1-(1+k)^{-t}}
$$

Situation 2 is similar to situation 1 with the exception of three distinctions. The first distinction is in charging the additional transfer fee, not according to the average, but according to the marginal rate of a machine-hour. The second distinction is the assumption about the lower demand for product $B$. In this regard, additional sales of product $\mathrm{B}$, which the manager of division $\mathrm{Z}$ can expect due to the removal of constraint on the production capacity of his own division and division $\mathrm{X}$, are only 57.56 thousand units per month. Column 4 of Table 5 shows that the set of projects will have a negative net present value of -10392 thousand rubles, which will result in a decrease in the economic profit of division $\mathrm{Z}$ and the entire company by 206.9 thousand rubles a month.

Nevertheless, there is a third circumstance that is not directly related to the ongoing operation of division $\mathrm{Z}$. It lies in the possibility of manufacturing new product $\mathrm{D}$ if there are enough free production capacities in division $\mathrm{X}$ to make the required components. The problem is that the capacities of division $\mathrm{X}$ that exist today are going to be engaged in the manufacturing of intermediate products for divisions $\mathrm{Y}$ and $\mathrm{Z}$ in the future. So the possibility of launching this project cannot be considered without making provision for expanding the production capacity of division $\mathrm{X}$. The expansion of the capacity of division X from 2100 to 2800 machine-hours a month is an example of such expansion that would make it possible to manufacture product $\mathrm{D}$ in the quantities required. In this regard, measures aimed at expanding the production of $\mathrm{X}$ and $\mathrm{Z}$, as well as the possibility of manufacturing 
product $\mathrm{D}$ should be evaluated as a single complex.

Though the current value of the project aimed at creating production of product $\mathrm{D}$ amounts to 75394 thousand rubles (which is less than the start-up costs for this project discounted at a risk-free rate), we have to take into account that in a year the market situation for this project may improve, and its present value may increase. Thus, it is necessary to consider not its current value but the value of the possibility of creating this production when the conditions of the potential market for product D improve, in other words, the value of the option of creating a new business segment. In our case, we have an analogue of the European "out-of-the-money" call option with the current value of the underlying asset of 75,394 thousand rubles, the strike price of 81,080 thousand rubles and the period of 12 months. The month-to-month risk-free rate is $0.25 \%$, and the standard deviation of the monthly yield on similar assets on the financial market is 0.1443 . Hence the value of this option by the Black Scholes formula is 13,614 thousand rubles.

Table 5. Indicators of the projects aimed at expanding production in divisions $\mathrm{X}, \mathrm{Y}$ and $\mathrm{Z}$ in situations $1-3$, thousand rubles

\begin{tabular}{|c|c|c|c|c|c|c|c|}
\hline \multirow[b]{2}{*}{ No. } & \multirow[b]{2}{*}{ Indicator name } & \multirow[b]{2}{*}{ Situation 1} & \multicolumn{2}{|l|}{ Situation 2} & \multicolumn{3}{|l|}{ Situation 3} \\
\hline & & & $\begin{array}{l}\text { excluding } \\
\text { the option }\end{array}$ & $\begin{array}{l}\text { when } \\
\text { subsidizing } \\
\text { the option }\end{array}$ & $\begin{array}{l}\text { where } \\
\text { there is a } \\
\text { mistake in } \\
\text { the com- } \\
\text { parison } \\
\text { base }\end{array}$ & $\begin{array}{l}\text { when there } \\
\text { is a mis- } \\
\text { take in the } \\
\text { identifica- } \\
\text { tion of the } \\
\text { constraint }\end{array}$ & $\begin{array}{l}\text { by TOC } \\
\text { algorithm }\end{array}$ \\
\hline 1 & 2 & 3 & 4 & 5 & 6 & 7 & 8 \\
\hline 10 & $\begin{array}{l}\text { Starting investments } \\
\text { for the purchasing and } \\
\text { assembly of additional } \\
\text { equipment, including: }\end{array}$ & 35100.0 & 35100.0 & 21486.0 & 43000.0 & 43000.0 & 13200.0 \\
\hline 11 & in division $\mathrm{X}$ & 29800.0 & 29800.0 & 16186.0 & 29800.0 & 29800.0 & 0.0 \\
\hline 12 & in division $Y$ & - & - & - & 13200.0 & 13200.0 & 13200.0 \\
\hline 13 & in division $\mathrm{Z}$ & 5300.0 & 5300.0 & 5300.0 & - & - & - \\
\hline 20 & $\begin{array}{l}\text { Increase in monthly } \\
\text { fixed costs (apart } \\
\text { from depreciation), } \\
\text { including: }\end{array}$ & 1580.0 & 1580.0 & 1580.0 & 1620.0 & 1620.0 & 580.0 \\
\hline 21 & in division $\mathrm{X}$ & 1040.0 & 1040.0 & 1040.0 & 1040.0 & 1040.0 & 0.0 \\
\hline 22 & in division $\mathrm{Y}$ & - & - & - & 580.0 & 580.0 & 580.0 \\
\hline 23 & in division $\mathrm{Z}$ & 540.0 & 540.0 & 540.0 & - & - & - \\
\hline 30 & $\begin{array}{l}\text { Marginal profit from } \\
\text { increase in monthly } \\
\text { sales, including: }\end{array}$ & 2360.0 & 2072.0 & 2072.0 & 2666.9 & 2461.5 & 1109.3 \\
\hline 31 & product A & - & - & - & 2666.9 & 2249.8 & 2249.8 \\
\hline 32 & product B & 2360.0 & 2072.0 & 2072.0 & 0.0 & 211.7 & -1140.5 \\
\hline
\end{tabular}




\section{Journal of Contemporary Management Issues}

\begin{tabular}{|l|l|l|l|l|l|l|l|}
\hline 40 & $\begin{array}{l}\text { Monthly net operation } \\
\text { cash flow on the } \\
\text { project }\end{array}$ & 780.0 & 492.0 & 492.0 & 1046.9 & 841.5 & 529.3 \\
\hline 50 & $\begin{array}{l}\text { Monthly annuity } \\
\text { payment to reimburse } \\
\text { investments } \\
\text { depreciation + normal } \\
\text { profit), including: }\end{array}$ & 698.9 & 698.9 & 427.8 & 856.2 & 856.2 & 262.8 \\
\hline 51 & in division X & 593.4 & 593.4 & 322.3 & 593.4 & 593.4 & 0.0 \\
\hline 52 & $\begin{array}{l}\text { in division Y } \\
53\end{array}$ & - & - & - & 262.8 & 262.8 & 262.8 \\
\hline in division Z & 105.5 & 105.5 & 105.5 & - & - & - \\
\hline 60 & $\begin{array}{l}\text { Increase in monthly } \\
\text { economic profit of } \\
\text { the company after } \\
\text { acceptance of a set of } \\
\text { projects }\end{array}$ & 81.1 & -206.9 & 64.2 & 190.7 & -14.8 & 266.4 \\
\hline 70 & $\begin{array}{l}\text { Net present value of a } \\
\text { set of projects }\end{array}$ & 4071.2 & -10392.0 & 3222.0 & 9575.1 & -742.5 & 13380.9 \\
\hline
\end{tabular}

Adding the value of the option of creating production of new product $\mathrm{D}(13,614$ thousand rubles) to the NPV of the set of projects aimed at expanding production in divisions $\mathrm{X}$ and $\mathrm{Z}(-10,392$ thousand rubles), we get a positive value of the adjusted NPV (3,222 thousand rubles). This indicates the advisability of launching projects in divisions $\mathrm{X}$ and $\mathrm{Z}$. However, since this option is not included in the area of responsibility of the manager of division $\mathrm{Z}$, equality (7) will be broken, and he will not initiate the project on expanding the manufacturing of product B. Since its deviation now can lead to a loss of the market share of product $\mathrm{B}$ in the future and can make launching product $\mathrm{D}$ on the market unreasonable even if the conditions are favorable, this can lead to lost profits for the company.

In order to get rid of the identified reason for dysfunctional behavior of the manager of division $\mathrm{Z}$ and to reestablish equality (7), investments in division $X$ should be reduced by the value of the option associated with them, as shown in column 5 of Table 5:

$\Delta C_{i}=\Delta F C_{i X}-\left(\Delta A_{i X}-G\right) \cdot \frac{k}{1-(1+k)^{-t}}$

In situation 3, the manager of division Y, who expects that the demand for product A will grow, is considering the possibility of expanding the production capacity necessary for making this product in quantities required by customers. According to the arrangements between the managers of divisions, division $Z$ has reserved 1,350 machine-hours of operation for the equipment of division $\mathrm{X}$ while division $\mathrm{Y}$ has reserved 750 machine-hours. Given the data in Tables 1 and 2, with these quotas, division $\mathrm{Z}$ will be able to make product $\mathrm{B}$ in quantities necessary for customers while division Y will be able to manufacture only 117.19 thousand units of product $\mathrm{A}$.

In order to boost the output of product A, division Y, first of all, has to increase its quota for the capacity of division $\mathrm{X}$ to at least 1,088 machine-hours, and at the same time to increase the capacity of its own division from a minimum of 1,375 up to 
1,870 machine-hours. In case the projects are accepted, the capacity of division Y will grow up to 2,070 machine-hours while its quota of the capacity of division $\mathrm{X}$ will go up to 1,450 machine-hours.

Let us assume initially that when we estimate the growth in cash flows related to the projects carried out by the manager of center $\mathrm{Y}$, the base is the production program, designed with its current quota for the capacity of division X (1,350 machinehours) and allowing to manufacture 117.19 thousand units of product A a month. With this base, we get a positive NPV and an increase in the economic profit of division $\mathrm{Y}$ (See column 6 of Table 5). As a result, its manager is likely to initiate these projects.

However, it can be easily shown that the production program, taken as the base for calculating the cash flows of the project, does not allow the best use of the key limited resource of the economic system. If there is no change, the production capacity of division $\mathrm{X}$ is going to be such a resource, while the product whose sales provide the highest marginal profit from a machinehour of operation of its equipment will be product A (7.89 thousand rubles per machine-hour versus 4.00 thousand rubles per machine-hour for product B). So to use the bottleneck of the company in the best way possible, 125.45 thousand units of product A and 144.12 thousand units of product B should be made. If such an optimal plan is used as the base for estimating cash flows, we get a negative NPV of the set of projects and a decrease in the economic profit of division $\mathrm{Y}$ in the future (see column 7 of Table 5). Thus, since the base is underestimated if a two-part transfer pricing system is used, the company could adopt a set of projects that would reduce its value and economic profit.
Nevertheless, even if such an optimal plan was used as a basis for calculations, it would not exclude another mistake, namely rejecting all possible investments from this complex by the manager of division Y. The fact is that when you accomplish a program that optimally uses the available resources of division $\mathrm{X}$, the main obstacle preventing the sales of product $\mathrm{A}$ from growing will be the available production capacity of division Y. So, the next measure to be evaluated in the chain of improvements of the organization's work should be the expansion of production capacity of division $\mathrm{Y}$ from 1,380 to 2,070 machine-hours, which, in fact, does not yet imply the expansion of production capacity of division $\mathrm{X}$. This can be explained by the fact that if the capacity of division $\mathrm{Y}$ was expanded, the output of product A could be increased up to 170 thousand units, also because the output of less profitable product $\mathrm{B}$ could decrease to 112.44 thousand units. The results of such changes are presented in column 8 of Table 5 and they show that this particular chain of actions complies with the rule of five focusing steps in the theory of constraints (TOC) (Dettmer, 1997; Corbett, 1998) and could lead to the greatest improvement in the performance of the company in the future.

\section{CONCLUSION AND DISCUSSION}

According to the results of the research study, it can be concluded that there a1re at least three circumstances that entail a risk of dysfunctional behavior of the managers of investment centers when they apply a two-part transfer pricing system. The first circumstance is that the expected values of the economic profit of the division that makes a decision to invest money are distorted because the transfer fee is estimated in management accounting systems 


\section{Journal of Contemporary Management Issues}

at average rates of the cost of resources, in particular that of the machine time of the division manufacturing the intermediate products. This can result in redistributing the expected increase in economic profit between several divisions - consumers of intermediate products and cause underestimation of the economic profit of the division that initiates the investment project as shown in situation 1 .

The problem in situation 1 could be solved if the transfer fee for the use of newly commissioned capacities is calculated not at average but at marginal rates of machine time. This would allow us to attribute additional current and capital expenses for the entire set of projects directly to the center - the initiator of these investments, regardless of the actual place where they arise. Nevertheless, using average rates, despite the difficulty in attributing additional costs directly to marginal rates in management accounting, has some rational grounds. Indeed, if additional units of equipment can be installed on the production floor, it means that at the time when the decision was being made the company had an option to expand it. Maintaining such an option could entail an increased level of costs calculated as machine-hours of operation of the equipment of the division manufacturing intermediate products. Before the production was expanded, all the divisions that consumed intermediate products had the burden of this option, so now they all, rather than just the project initiator, have the right to receive some saving from the project.

Thus, there is a paradox in this transfer pricing system, which represents something more than the convenience of using average rates in accounting calculations. In its essence, it is associated with an attempt to represent a complex system in management accounting as a number of simple parts.

The second circumstance is that the divisions analyzing the effectiveness of the investments they initiate are likely to limit themselves to evaluating the consequences directly related to their area of responsibility. In this regard, they will not consider real options related to the project in other segments of the company as shown in situation 2.

This problem could be solved if investments into the project equal to the amount of the option value are subsidized by the head office of the company, which would allow the initiator to predict an increase in economic profit. However, in order to bring about the question of subsidies, initiator $\mathrm{Z}$ needs to have information about the option. The lack of such information can result in project being rejected even before it is agreed on with the head office of the company. Therefore, the lack of information on such options at investment centers can become one of the main constraints of such transfer pricing systems and be the reason why the headquarters of the company should have to intervene in the investment activities of the divisions.

The third circumstance is the failures of constraint management if two-part transfer pricing is used as shown in situation 3 . Such failures can be incorrect identification of the constraint itself, which can end up in rejection of projects that can eliminate the actual constraint of the system and increase the value of the business. In addition, the decisions to increase the amount of the capital resource that constrains the system operation may be considered as failures if they are made before all possible measures have been taken to ensure the most effective use of this resource. As a result, when the consequences of such a decision are assessed, 
the base for calculating an increase in cash flows due to the adopted projects is underestimated, which can lead to overstatement of their value and the adoption of projects whose NPV is actually negative.

When transfer pricing is decentralized and there are internal production resource constraints of the system, such dysfunctional decisions can be avoided if there is a well-developed intra-company market for long-term contracts for the right to use the capacity of related divisions. In situation 3, division $Y$ could buy back from division $\mathrm{Z}$ the right to use the missing capacity of unit $\mathrm{X}$ in the future, reimbursing division $\mathrm{Z}$ the corresponding part of the transfer payment and the profit it did not receive. However, if the production structure were more complex, the investment centers might not have the information necessary for such optimal quasi-market behavior.

It is obvious that the reasonability of using two-part transfer pricing systems in the activities of investment centers can only be assessed accurately in each specific case. However, as our investigation has shown, the risks of losses and lost profits associated with the use of these systems are obvious while the advantages they may have in comparison with centralized management are doubtful.

\section{References}

1. Bierman, H. Jr., 1959. Pricing Intracompany Transfers. The Accounting Review, 34 (3), 429-432.

2. Buus, T. \& Brada J., 2008. On the Necessity of Using Average Cost as a Base for Transfer Price. European Financial and Accounting Journal, 3 (3), 79-94.

3. Coase, R.H., 1937.The Nature of the Firm. Economica, 4 (16), 386-405.
4. Corbett, T., 1998. Throughput Accounting: TOC's Management Accounting System.Great Barrington, MA: The North River Press.

5. Dettmer, W., 1997. Goldratt's Theory of Constraints: A Systems Approach to Continuous Improvement.Milwaukee, WI: ASQ Quality Press.

6. Goldratt, E., 1990. The Haystack Syndrome: Sifting Information Out of the Data Ocean. Croton-on-Hudson, NY: The North River Press.

7. Göx, R.F., 2000. Strategic transfer pricing, absorption costing and observability. Management Accounting Research, 11 (3), 327-348.

8. Hayes, B., 1987. Competition and Two-Part Tariffs. Journal of Business, 60 (1), 41-54.

9. Hirshleifer, J., 1956. On the Economics of Transfer Pricing. The Journal of Business, 29 (3), 172-184.

10. Horngren, C., Foster, G. \& Datar, S., 1997. Cost Accounting: A Managerial Emphasis. Annotated Instructor's Edition. 9th ed. Englewood Cliffs: Prentice-Hall.

11. Kaplan, R. \& Atkinson, A., 1998. Advanced Management accounting.3rd ed. Upper Saddle River: Prentice Hall.

12. Lantz, B., 2009. The double marginalization problem of transfer pricing: Theory and experiment. European Journal of Operational Research, 196(2), 434-439.

13. Luther, R. \& Zverovich, S., 2010. A multiple price approach to limiting intra-group transfer pricing negotiations. International Journal of Management Accounting Research, 3 (2). https:// uwe-repository.worktribe.com/output/974823 (Accessed on: 08.09.2019) 


\title{
Journal of Contemporary Management Issues
}

14. McAulaya, L., Scrace, A. \& Tomkins, C., 2001.Transferring priorities: a three-act play on transfer pricing. Critical Perspectives on Accounting, 12 (1), 87-113.

15. Pfeiffer, T., Schiller, U. \& Wagner, J., 2011. Cost-based transfer pricing. Review of Accounting Studies, 16 (2), 219-246.

16. Sahay, S.A., 2003. Transfer Pricing Based on Actual Cost. Journal of Management Accounting Research, 15 (1), 177-192.

17. Samuels, J. M., 1969. Penalties and subsidies in internal pricing policies. Journal of Business Finance, 3, 31-38.

18. Schlereth, C., Stepanchuk, T. \& Skiera, B., 2010. Optimization and Analysis of Profitability of Tariff Structures with Different Number of Two-Part Tariffs. European Journal of Operational Research, 206 (3), 691-701. 8
19. Tomkins, C., 1990. Making sense of cost-plus transfer prices where there are imperfect intermediate good markets by a 'pragmatic-analytical' perspective. Management Accounting Research, 1(3), 199-216.

20. Tomkins, C., 1975. Another Look at Residual Income. Journal of Business Finance and Accounting, 2 (1), 39-53.

21. Vaysman, I., 1996. A model of costbased transfer pricing. Review of Accounting Studies, 1 (1), 73-108.

22. Williamson, O. E., 1985. The Economic Institutions of Capitalism: Firms, Markets, Relational Contracting.NY: Macmillan and Free Press.

23. Young, D.W., 1998. Two-part transfer pricing improves IDS financial control. Healthcare Financial Management, 52 (8), 56-65.

\section{DISFUNKCIONALNOST DVOSMJERNOG ODREĐIVANJA TRANSFERNIH CIJENA U ODREĐIVANJU UČINKA INVESTICIJSKIH CENTARA}

\begin{abstract}
Sažetak
U ovom se radu raspravlja o mogućnostima sustava dvosmjernog određivanja transfernih cijena za poticanje investicijskih centara za odbijanje projekata s pozitivnom neto sadašnjom vrijednošću, odnosno prihvaćanje projekata s negativnom neto sadašnjom vrijednošću, u slučaju kada ne postoji vanjsko tržište međuproizvoda. Utvrđuje se u kojim uvjetima investicijski centri mogu donositi tako disfunkcionalne odluke te se istražuje kako se odgovarajući sustavi mogu modificirati, kako bi se uklonili negativni efekti. Za rješavanje navedenih problema, koriste se metode financijske analize, teorije realnih opcija i teorije ograničenja te se modelira nekoliko hipotetskih poslovnih situacija, kojima se prikazuju posljedice mogućeg disfunkcionalnog ponašanja investicijskih centara, u uvjetima decentraliziranog strateškog odlučivanja. U radu se razmatraju razlozi za donošenje ovakvih odluka, kao što su korištenje prosječnih stopa troškova resursa u kalkulaciji transfernih plaćanja, prisustvo realnih opcija u povezanim projektima te narušavanje pet koraka fokusiranja u okviru teorije ograničenja.
\end{abstract}

Ključne riječi: transferne cijene, dvosmjerni sustavodređivanja transfernih cijena, decentralizacija, investicijski centar, ekonomski profit, realna opcija, teorija ograničenja 